\title{
THE ROLE OF YOUNG FARMERS GROUP IN NEW MEDIA UTILIZATION FOR YOUNG HORTICULTURAL AGRIPRENEURS IN YOGYAKARTA SPECIAL REGION, INDONESIA
}

Siti Nurlaela ${ }^{1}$, Sunarru Samsi Hariadi ${ }^{2^{*}}$, Alia Bihrajihant Raya ${ }^{3}$

${ }^{1}$ Extension and Development Communication Study Program, Graduate School of Universitas Gadjah Mada (UGM), Yogyakarta, Indonesia, and Politeknik Pembangunan Pertanian Yogyakarta-Magelang, Indonesia; ${ }^{2 *, 3}$ Extension and Development Communication Study Program, Graduate School of Universitas Gadjah Mada (UGM), Yogyakarta, Indonesia, and Agricultural Extension and Communication Study Program, Department of Agriculture Socio-

Economics, Faculty of Agriculture, Universitas Gadjah Mada (UGM), Yogyakarta, Indonesia.

Email: ${ }^{1}$ nurlaela77yk@gmail.com, ${ }^{2 *}$ sunarru_sh@ugm.ac.id, ${ }^{3}$ alia.bihrajihant.r@ugm.ac.id

\section{Article History: Received on $01^{\text {st }}$ April 2020, Revised on $15^{\text {th }}$ May 2020, Published on $26^{\text {th }}$ May 2020}

\begin{abstract}
Purpose of the study: This study is to analyze the characteristics of young farmers in horticultural agripreneurs, the role of young farmers group, the utilization of new media in horticultural agripreneurs, and the influence of the characteristics of young farmers and the role of groups on the utilization of new media in horticultural entrepreneurs
\end{abstract}

Methodology: This research used the survey method. A simple random sampling method was used in selecting 300 of 604 young farmers, consisting of 250 men and 50 women. The role of young farmers group and the utilization of new media variables are measured using a 5-score rating scale, which includes; (1) never, (2) rarely, (3) sometimes, (4) often, (5) always. Data were analyzed using percentages, mean scores, and multiple regression tests at $\mathrm{p} \leq 0.05$.

Main Findings: The results showed that young farmers most often use smartphones to access social media. The majority of farmers use WhatsApp for their daily communication. Factors influencing the utilization of new media (Y) included gender (X1), an education level (X2), length of business (X3), and the role of farmer group (X4) together (Rsquare) of $34.7 \%$. The role of young farmer groups and sex had a positive effect on the utilization of new media; length of business had a negative effect, while education level did not affect the use of new media $(p \leq 0.05)$.

Applications of this study: The government is expected to encourage young agripreneurs in Yogyakarta Special Region, Indonesia, who are just starting a business to utilize new media by empowering groups to conduct training and learning to become successful young agripreneur.

Novelty/Originality of this study: This study found that the role of young farmers group as a means of social learning is very important in horticultural agripreneurs, especially for young farmers in rural areas who are just starting a business with the use of new media to develop their businesses.

Keywords: Horticultural Agripreneur, Agriculture Entrepreneurship, Group Role, New Media, Young Farmers.

\section{INTRODUCTION}

Advances in information technology have changed human behavior in all aspects of life, not least in agriculture. Utilization of information technology provides an excellent opportunity for the development of the agricultural sector, but most farmers have not used information technology to support Farming (Kutwa et al., 2016), (Agu, 2013). This is indicated by data that only $20.45 \%$ of farmers use new media to support Farming (KOMINFO RI, 2015).

The role of young farmer groups is very important in rural Farming (Kutwa et al., 2016). Activities of young farmers can be accommodated in groups, including discussions, visits, and creating a horticultural auction market (Raya, 2014), (Magnan et al., 2015). New media is one of the most effective tools in supporting group activities. The role of groups in increasing the use of new media can be an effort to develop horticultural agriculture. The characteristics of the same age are considered quite useful as a vehicle for mutual learning between them. The occurrence of a social learning process among young farmers can develop their Farming. The effectiveness of social learning in this group of young farmers is found in the gardening community (Rogge et al., 2020). The effectiveness of the social learning process among young peers of the same age is considered more effective as (Santrock, 2012) opinion states that friends become important in meeting social needs. Positive peer groups will have a good influence on youth, and vice versa. The group of young farmers as a factor that plays an important role is also found on (Conley \& Udry, 2001), (Noorani, 2015), and (Hoffmann et al., 2007) research which states that young farmers consider the success of family, friends, or neighbors to be motivations in doing business. The importance of grouping these young farmers can be used to discuss a lot of new information such as new media for agriculture.

Schroeder (2018) states that new media is a variety of communication technology devices that share the same characteristics which, in addition to being made possible by digitalization and its full availability for personal use as a means of communication, with the main feature of new media being interconnectedness, and interactivity between personal and mass. New media in this research was the internet through smartphones. The function of new media in agriculture can make farm activities easier, as a result of (FAO, 2017) research. Farmers use the internet to obtain 
information and manage this information in developing their farming business and can improve income (Faith, 2013). Subejo et al., (2018) also state that the highest use of the internet among farmers is to find information related to cultivation, and the second to find information on processing agricultural products.

Based on the explanation above, this research will contribute to the role of groups in entrepreneurship and its influence on the use of new media. Based on the explanation above, this research will contribute to the role of groups in entrepreneurship and their influence on the use of new media. The findings of this study are expected to explain that the group's goals in the current era of information technology are still significant, and can even support the use of new media to be more effective in developing business. Amid farmers' current regeneration problems, the use of information technology can be an attraction for youth to enter the world of agriculture.

\section{THEORETICAL FRAMEWORK AND HYPOTHESIS}

\section{Theoretical Framework}

This research uses Social Learning Theory from Albert Bandura which states that a person's behavior is influenced by their environment. Someone will follow the behavior of others who are considered interesting and useful. Social learning can run effectively with a role model. Social Learning Theory by Bandura states that steps of the social learning process are; attention, retention, motor reproduction, reinforcement, and motivation (Harinie et al., 2017), (David, 2015), (Schneider et al., 2009). Farmers can learn from each other through the process of social learning in groups to improve their Farming (Laforge \& McLachlan, 2018), (Dessie et al., 2013) and (Benyishay \& Mobarak, 2019). The most important physiological function in social learning theory is the emphasis on the continuous reciprocal interaction between these three factors. Behavior can affect personal factors, on the contrary, the individual cognitive activity can affect, the environment. Environmental influences can change individual thought processes. Environmental factors in this study are the role of groups, while the characteristics of young farmers (gender, education levels and length of business) are personal factors. The behavior of using new media is the result of the interaction between the two factors, illustrated in Figure 1.

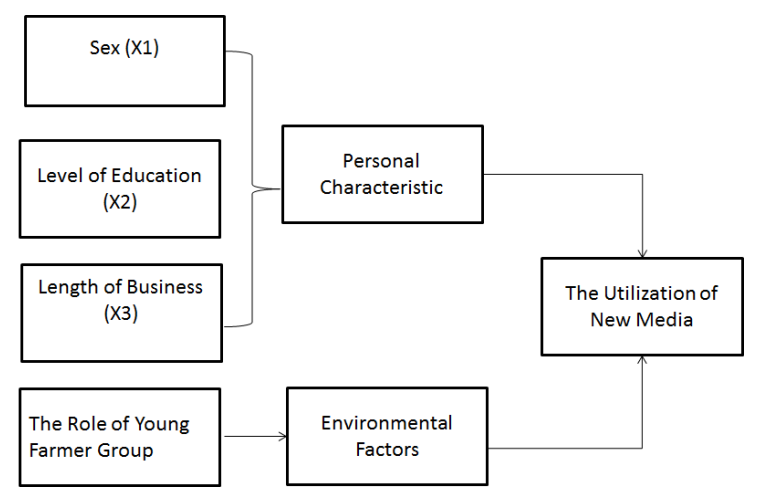

Figure 1: Relationship between variables in the research mode

The group of young horticultural farmers in this study acted as a vehicle for learning, collaboration, and networking, as per opinion Elizabeth \& Anugrah (2014), and Adong et al., (2013). The group of young peers who are peers plays a supporting environmental factor in agricultural entrepreneurship, especially in the use of new media for business. Youth are the most active users, especially using social media for communication (Kahar et al., 2012), (Rani \& Padmalosani, 2019). The average teenager spends 6.5 hours a day and continues to increase in terms of online media (Santrock, 2012). If this trend can be put to good use, it becomes an opportunity to develop the agricultural sector to become more modern and attractive to the younger generation.

\section{Hypothesis}

Personal characteristics and external factors can influence young farmers in agricultural entrepreneurship.(Sulaksana, 2011). In line with the research, education level and the role of external factors can influence entrepreneurial behavior, including in the use of new media based on Anwarudin et al., (2019) research. Meanwhile, Subejo et al., (2018) state that the level of education and gender influence the use of information technology in business. Based on the previous research, the hypothesis is arranged as follows:

H0: Gender, education level, length of business and the role of young farmers groups together not influence on the utilization of new media in agripereneur,

H1: Gender, education level, length of business, and the role of young farmers groups together influence on the utilization of new media in agripreneur.

Hypotheses test is employed to find out whether there is influence between variables in this research model. This effect is significant if the F-calculated value is higher than the F-table at a significance level of $p \leq 0.01$. 


\section{METHODOLOGY}

The study was conducted in a horticultural commodity-producing region based on horticultural productivity data of the Department of Agriculture, Yogyakarta Special Region. The region includes three districts, namely, Bantul, Kulonprogo, and Sleman (Figure 2). The criteria for respondents are young farmers with the age range of 20-40 years and in a group. The determination of the research area is based on the village with the highest productivity based on data from the Special Region of Yogyakarta Agriculture Office. The sampling method was done by a simple random sampling that employed 300 out of 604 young farmers, consisting of 250 men and 50 women.

Data collection was done by the use of a closed questionnaire. Research variables consist of dependent and independent variables. The dependent variable is the utilization of new media in agripreneurship, and independent variables include the role of young farmers group, sex, education level, and length of business. The role of the group consists of a vehicle for learning, collaboration, and networking. The utilization of new media includes finding information, establishing communication, and conducting transactions. The variable is measured using a five-score rating scale, which includes; (1) never, (2) rarely, (3) sometimes, (4) often, (5) always. Determinant factors in the form of sex are (1) for men, and (0) for women, education level which is calculated based on years of education: Elementary School (6 years), Junior High School (9 years), Senior High School (12) years), Higher Education/University (17 years). Percentages and average scores are used to analyze the personal characteristics of young farmers. To determine the effect of independent variables on the dependent variable using multiple regression tests. The statistical model is as follows: $\mathrm{Y}=\mathrm{k}+\mathrm{aX} 1+$ $\mathrm{bX} 2+\mathrm{cX} 3+\mathrm{dX} 4$

Description:

Y: The utilization of new media

\section{$\mathrm{X} 1$ : Sex}

X2: Level of education

X3: Length of business

$\mathrm{X} 4$ : The role of young farmers group

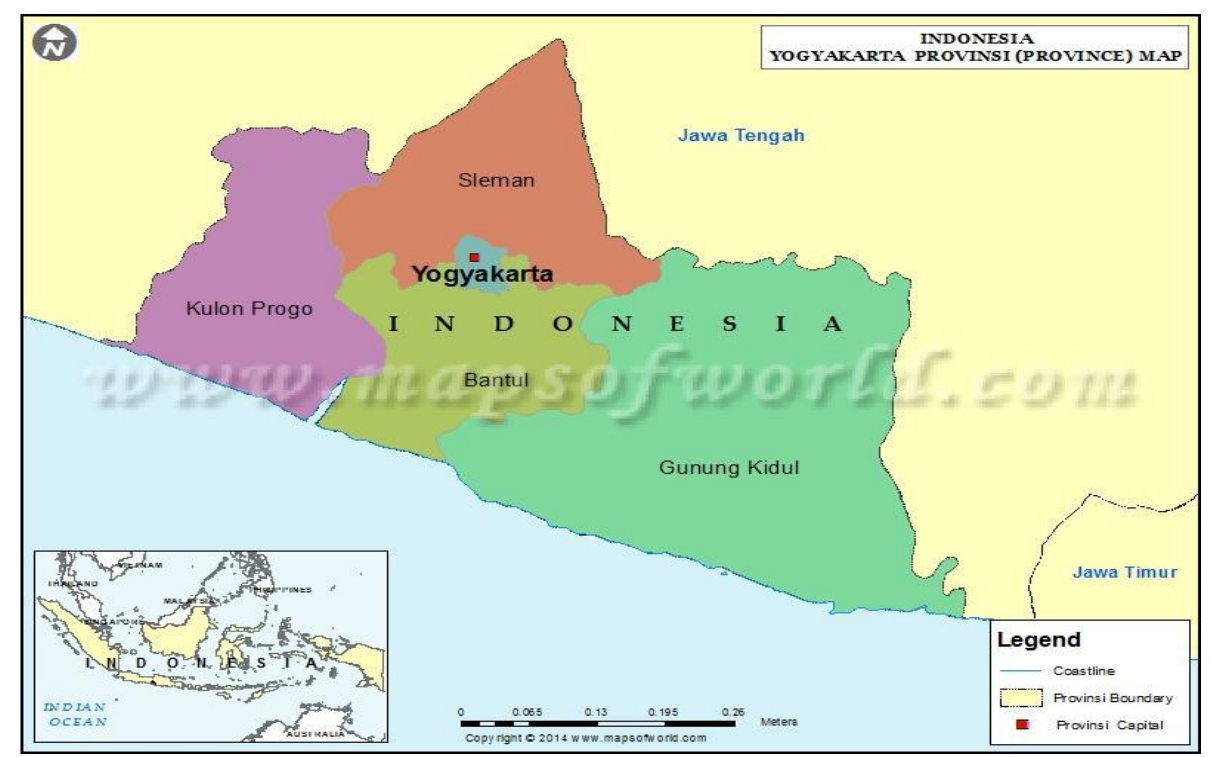

Figure 2: Map of The Special Region of Yogyakarta, Indonesia

Source: https://www.mapsofworld.com/indonesia/provinces/yogyakarta.html

\section{RESULTS AND DISCUSSION}

\section{Characteristics of Horticultural Young Farmers}

Table 1 shows that the majority of young farmers were male (83.33\%). Farming work requires physical strength, so the role of the male is more needed in cultivation. This result is following research Subejo, et al (2018), which states that agricultural activities especially production are mostly carried out by men. Regarding the education level, most of the young farmers (74\%) graduated from High School / Vocational High School, This data is following Anwarudin, et al $\underline{(2019)}$ and Rasmikayati, et al (2017), which states that young farmers have a relatively high level of education than older farmers. It is expected that the adoption and innovation process can be better, especially in the use of new media (Makalew et al., 2013). While the average length of business was 8.25 years. 
Table 1: Characteristics of Young Horticulture Agripreneurs

\begin{tabular}{|c|c|c|c|c|}
\hline Variable & $\begin{array}{l}\text { Number of } \\
\text { farmers }\end{array}$ & $\begin{array}{c}\text { Percentage } \\
(\mathbf{n}=\mathbf{3 0 0})\end{array}$ & Mean & $\begin{array}{l}\text { Standard } \\
\text { Deviation }\end{array}$ \\
\hline \multicolumn{5}{|l|}{ Sex (X1) } \\
\hline Man & 250 & 83.3 & & \\
\hline Woman & 50 & 16.67 & & \\
\hline \multicolumn{5}{|l|}{ Education (X2) } \\
\hline Elementary School & 4 & 1.33 & & \\
\hline Junior High School & 40 & 13.33 & & \\
\hline Senior High School & 222 & 74 & 12.07 & \\
\hline University (Higher Education) & 34 & 11.33 & & \\
\hline \multicolumn{5}{|l|}{ Farming duration (years) (X3) } \\
\hline $0-5$ & 119 & 39 & & \\
\hline$>5-10$ & 113 & 38.33 & 8.25 & 5.24 \\
\hline$>10-15$ & 40 & 13.33 & & \\
\hline$>15$ & 25 & 9.33 & & \\
\hline
\end{tabular}

Source: Field Survey (2019)

\section{Young Farmers Group in Horticultural Entrepreneurship}

Farmers' group is a group of farmers formed by farmers based on shared interests, shared social, economic, and resource conditions, shared commodities, and familiarity to improve and develop member businesses (Regulation of the Minister of Agriculture of the Republic of Indonesia Number 33/Permentan/SM.23/7/2016). The role of groups in agricultural entrepreneurship includes the community as a vehicle for learning, cooperation, and building networks. Table 2 shows that the role of the group is rarely to support their agricultural entrepreneurs (2.92). The role of community is beneficial in building networks (3.21), because building networks is essential for developing businesses, especially in terms of marketing. Efforts to build networks can be made with markets, stakeholders and the government, and the private sector. It is consistent with the results of Fischer \& Qaim (2012) and (Chell \& Baines's, 2000) research, which states that business networking is one of the group's social capital that can improve marketing performance.

Table 2: Roles of Community in Agricultural Entrepreneurship

\begin{tabular}{ccc}
\hline Community Role & Mean & Std. Deviation \\
\hline Learning & 2.48 & 0.65 \\
\hline Cooperation & 3.08 & 0.75 \\
\hline Networking & 3.21 & 0.67 \\
\hline $\mathrm{N}=300$, Mean Total & 2,92 & \\
\hline
\end{tabular}

Source: Field Survey (2019)

The group as a vehicle for cooperation (3.08) can create an atmosphere of mutual help and closeness between members. The cooperation carried out, for example, the supply of seeds and fertilizer, as well as the management of agricultural equipment and machinery in groups. Farmers need to work together in groups or associations so that they can produce more efficiently, be able to deal with intermediary traders and markets more strongly (Barham et al., 2018), (Courtois \& Subervie, 2014), (Agu, 2013), (Hoffmann et al., 2007). The group, as a learning vehicle (2.48). It shows that there is a shift in the function of the group, which initially became a means of learning in the formal sense with extension agents into groups that learn from one another with various means, one of which is new media. The role of new media can be a means of increasing creativity and innovation so that the role of groups as a vehicle for learning can continue to develop. On the other hand, Zhang, et al (2016) states that the need for the use of media encourages learning in groups through senses, the results of which will increase farmers' knowledge. To attract members to participate in learning activities in groups, groups can arrange activities that support information literacy as an effective learning vehicle, especially in the use of new media.

\section{Utilization of New Media in Agricultural Entrepreneurship}

The use of new media in agripreneurship is the effort of young farmers in finding information, communication, and transaction using new media. New media in this research was the internet through smartphones, as (Ogunniyi \& Ojebuyi, 2014) research. Young farmers most often use smartphones to access social media. Social media has become a means of communication for everyone, including the farmers. The role of social media can be used to improve the ability of entrepreneurs to find new opportunities, as Park (2017) and Chikaire, et al (2015), research. Table 3 shows that the majority of farmers use WhatsApp for their daily communication (85\%), followed by Facebook (40\%) and the least is SMS (Short Message Service) (9,67\%). This SMS has been abandoned and has shifted to new media They chose the 


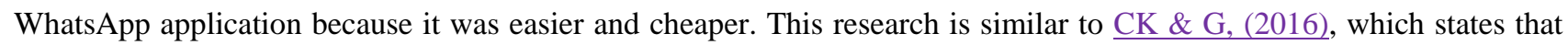
WhatsApp is the practical use of social media and mostly preferred for related groups.

Table 3: The Used of Social Media for Entrepreneurs

\begin{tabular}{ccc}
\hline Type Of Social Media & Amount & Percentage (\%) \\
\hline Whatsapp & 255 & 85 \\
\hline Facebook & 120 & 40 \\
\hline Instagram & 80 & 26,67 \\
\hline Line & 40 & 13,33 \\
\hline Twitter & 30 & 10 \\
\hline SMS & 29 & 9,67 \\
\hline Don't Have & 2 & 0,67
\end{tabular}

Note: Respondents can write more than one social media $(\mathrm{N}=300)$

Source: Primary Data Analysis (2019)

According to Table 4, the mean of using new media support their Farming is $(\bar{x}=3.02)$. In the salak commodity field area, the research found that young farmers groups combine the potential of agriculture with tourism, and they do promotions using websites and other social media (Instagram, Facebook, WhatsApp).

Table 4: Utilization of New Media in Entrepreneurship

\begin{tabular}{lll}
\hline Statemen & Mean & SD \\
\hline Utilizing new media to find capital information & 2,92 & 0,09 \\
\hline Utilizing new media to find information about innovations in cultivation & 3,5 & 0,49 \\
\hline Utilizing new media to find marketing information & 3,36 & 0,35 \\
\hline Utilizing new media to find information on processing agricultural products & 3,29 & 0,28 \\
\hline Utilizing new media to find information on creative farming businesses & 3,41 & 0,4 \\
\hline Searching for information & $\mathbf{3 . 2 9}$ \\
\hline Interact with fellow young farmers & 3,43 & 0,42 \\
\hline $\begin{array}{l}\text { Take advantage of new media to be active in the social media of the young farmer's } \\
\text { community }\end{array}$ & 2,96 & 0,05 \\
\hline $\begin{array}{l}\text { Collaborate with providers of agricultural applications for consultations on cultivation } \\
\text { techniques }\end{array}$ & 2,74 & 0,27 \\
\hline Utilize new media to receive input / suggestions & 2,58 & 0,43 \\
\hline Utilize new media to collaborate with production input providers & 2,71 & 0,3 \\
\hline Establish communication & $\mathbf{2 . 8 8}$ \\
\hline Utilizing new media to sell products & 2,81 & 0,2 \\
\hline Utilizing new media to receive orders & 2,71 & 0,3 \\
\hline Utilize new media to enhance marketing with e-commerce & 3,09 & 0,08 \\
\hline Utilize new media to interact with buyers & 3,1 & 0,09 \\
\hline Utilizing new media to improve marketing through agricultural application systems & 2,67 & 0,34 \\
\hline Making Transactions & $\mathbf{2 . 8 7}$ \\
\hline Average Mean & $\mathbf{3 . 0 2}$
\end{tabular}

Source: Field Survey (2019)

According to Table 4, the highest mean use of new media for young farmers was to look for information (3.29). Young farmers most often seek information about innovations in cultivation such as drip irrigation, mulching, and pest management. They rarely use it to find information on capital, because they use groups or banks to borrow capital. The search for information carried out can be genuinely beneficial for Farming, and farmers are expected to have excellent information literacy skills. Information literacy is the ability to search, evaluate, and use the information effectively so that users can achieve benefit (Raya et al., 2018). The ability of functional information literacy will foster creativity in entrepreneurship. This study found that creativity in cultivation, such as planting various kinds of commodities, mulch use, spacing, and water management, are some of the innovations made by young farmers in the Special Region of Yogyakarta.

The second means is to establish communication (2.88). Interaction among young farmers is the most frequent activity, on the other hand, communication with input production providers is rarely done $(2,88)$. The need for groups with peers is an essential aspect of social development at a young age. According to Vidanapthirana, et al (2019) the role of new media in young farmers has led to the birth of social media-based farming communities such as Facebook, Whatsapp, and other applications to communicate with one another. This is based on Table 3 that the use of social media in young 
farmers can support communication in agricultural business. Young farmers most often communicate among young farmers in the WhatsApp group.

The last mean was in making transactions (2.87). In the transaction indicator, young farmers most often use new media to interact with buyers, whereas what is rarely done is to use e-commerce to increase marketing because of the lack of understanding and skills in operating e-commerce $(2,87)$. The transaction process is usually done with traders in the management of the chili auction market. This research is similar to Rusdiyana (2018), which states that the group auction market is the choice of farmers because it is most profitable for farmers. In salak farmers with tourists, meanwhile onion farmers with traders, whereas direct communication with buyers has started with some farmers and has personal skills, not through groups, according to Jamaluddin (2013) research. Training and human resource capabilities based on groups are needed so that farmers can using agricultural application systems to support marketing.

\section{Determinants of New Media Utilization in Agricultural Entrepreneurship}

Table 5 shows the influence of gender, the period of the business, and the community's role together on the use of new media in agricultural entrepreneurship ( $\mathrm{R}$ Square 34.7\%). This effect is significant because the F-calculated value (39.21) is higher than the F-table (3.41) at a significance level of $p \leq 0.01$. The model of the influence of each variable in a row, that is, gender and group roles, has a positive effect; the length of business has a negative effect, while the level of education does not affect the use of new media in agricultural entrepreneurship.The equation can be stated as follows: $\mathrm{Y}$ $=2,813+1,005 \mathrm{X} 1$ (dummy) $+-0,074 \mathrm{X} 3+0.051 \mathrm{X} 4$.

Table 5: Determinants New Media utilization in Agricultural Entrepreneurship

\begin{tabular}{cccc}
\hline Variable & Regression Coeff. & T-Calc. & Sign \\
\hline Sex (X1) (dummy) & 1.005 & 1.020 & $0.038^{*}$ \\
\hline Education (X2) & 0.173 & 0.822 & 0.412 \\
\hline Period of Business (X3) & -0.074 & -3.438 & $0.001^{*}$ \\
\hline Group Role (X4) & 0.051 & 11.176 & $0.000^{* *}$ \\
\hline Constant & 2.813 & & \\
\hline R-Square & 0.347 & & \\
\hline Adjusted R Square & 0.338 & & \\
\hline F-Calc. & 39.214 & & \\
\hline
\end{tabular}

Note: *Significant on the level of $0.05, * *$ Significant at 0.01

Source: SPSS version 24

This research found that sex has a positive effect on the utilization of new media,(man multiplied by 1 , woman multiplied by 0 ). The meaning is young men farmers use more new media than women because agricultural entrepreneurs require more physical abilities. Business experience has a significant adverse effect on the use of new media, meaning that the longer the farmer conducts agripreneur, the lower the level of utilization of new media. Each increase the length of business of 1 (one) point can decrease the utilization of new media by 0.074 points. The research shows that farmers who have long been in entrepreneurship have experience in cultivation and networks that have developed, and are running stably. Research with similar results as Kabir (2012), reported that long experienced farmers were not interested in adding skills in utilizing new media.

The role of groups has a significant effect on the use of new media (Table 5). Each increase in the role of the group of 1 (one) point can increase the utilization of new media by 0.051 points. Farmers who join the group will get a more developed opportunity than young farmers who have not participated in the group. Interaction in groups allows the process of social learning. Utilizing new media supported by social learning processes in this group can help entrepreneurial success. Hariadi (2011) states that strong interaction between members will allow many ideas to emerge so that the group can function to increase success as a unit of learning, cooperation, production, and business. The success of the social learning process can improve the ability to take advantage of new media.

The use of new media for young farmers can be in the form of communication and direct transactions with consumers so that they get better prices. Young farmers groups have used information technology to empower their members through developing entrepreneurship, accessing market opportunities, trying to solve business problems, and increasing market expansion. It is important to strengthen young farmers who are just starting a business because it will influence the use of new media, such as Faith's research (2013). The emergence of new media in agriculture can make it easier for farmers to access information, establish communication and transactions. Developing the ability of young farmers to use new media is one of the most effective efforts, as a result of research Prayoga, et al (2019) and Lokeswari (2016) that agriculture will advance with information technology. 


\section{CONCLUSION}

This research contributes to two aspects, the role of groups in the use of new media and the utilization of new media in young farmer entrepreneurship. First, it shows that the occurrence of interaction in groups and social learning processes can have a positive impact on optimizing the use of new media. The presence of the group will encourage its members to utilize new media in business. The transaction process using a new group-based media is considered quite successful, for example, in managing the auction market. Second, young farmers who are just starting in entrepreneurs use new media more often than farmers who are conducting entrepreneur longer. Meanwhile, the utilization of new media is limited mostly for seeking information. Young farmers are encouraged to use new media to enlarge networking with others through communication. To have a bargaining position toward the market, new entrepreneurs should optimize the function of new media.

It is hoped that with increasing the role of groups, the use of new media, which is currently limited for information seeking, will be further developed for communication and transaction facilities that support marketing, so farmers have the reliable bargaining power to the market and consumers.

From the results of this study, the government is expected to continue to encourage and facilitate the use of new media, especially for young farmers who are just starting entrepreneurship because they need more information and networks to develop their businesses. The facilitation includes group-based business management especially to improve marketing through an agricultural application that supports marketing, training in utilizing the internet for cultivation, and maximizing the function of social media for marketing so that they become successful young agripreneur.

\section{LIMITATION AND STUDY FORWARD}

The limitations of this study are only in one province. Further researchers are expected to conduct more extensive research throughout Indonesia to obtain more complete results related to the use of new media in young farmers.

\section{AUTHORS CONTRIBUTION}

All authors contributed to this study. The first author conducted research and writing. The second author reviewed and provided improvements. The third author translates and perfects writing.

\section{REFERECES}

1. Adong, A., Mwaura, F., \& Okoboi, G. (2013). What Factors Determine Membership to Farmer Groups in Uganda? Evidence from the Uganda Census of Agriculture 2008/9. Journal of Sustainable Development, 6(4). https://doi.org/10.5539/jsd.v6n4p37

2. Agu, M. N. (2013). Application of ICT in Agricultural Sector: Women's Perspective Monica. International Journal of Soft Computing and Engineering (IJSCE), 2(6), 58-60.

3. Anwarudin, O., Sumardjo, S., Satria, A., \& Fatchiya, A. (2019). Factors Influencing the Entrepreneurial Capacity of Young Farmers for Farmer Succession. International Journal of Innovative Technology and Exploring Engineering, 9(1), 1008-1014. https://doi.org/10.35940/ijitee.A4611.119119

4. Barham, J., Barham, J., \& Chitemi, C. (2018). Collective Action Initiatives to Improve Marketing Performance: Lessons from Farmer Groups in Tanzania. Food Policy, 34(1), 53-59. https://doi.org/10.1016/j.foodpol.2008.10.002

5. Benyishay, A., \& Mobarak, A. M. (2019). Social Learning and Incentives for Experimentation and Communication. Review of Economic Studies, 86(3), 976-1009. https://doi.org/10.1093/restud/rdy039

6. Chell, E., \& Baines, S. (2000). Networking, entrepreneurship and microbusiness behaviour. Entrepreneurship and Regional Development. https://doi.org/10.1080/089856200413464

7. Chikaire, J. U., Ani, A. O., Nnadi, F. N., \& Godson-Ibeji, C. C. (2015). Analysis of information and communication technology roles in poverty reduction among small and medium scale farmers in Imo State, Nigeria. Library Philosophy and Practice.

8. CK, J., \& G, R. (2016). Social Media and Farmers. International Journal of Research in Engineering and Technology, 05(31), 20-25. https://doi.org/10.15623/ijret.2016.0531004

9. Conley, T., \& Udry, C. (2001). Social Learning Through Networks: The Adoption of New Agricultural Technologies in Ghana. American Journal of Agricultural Economics. https://doi.org/10.1111/0002-9092.00188

10. Courtois, P., \& Subervie, J. (2014). Farmer Bargaining Power and Market Information Services. American Journal of Agricultural Economics, 97(3), 953-977. https://doi.org/10.1093/ajae/aau051

11. David, L. (2015). Social Learning Theory Bandura Social Learning Theory. Learning Theories, October, 2-3. https://www.learning-theories.com/social-learning-theory-bandura.html

12. Dessie, Y., Schubert, U., Wurzinger, M., \& Hauser, M. (2013). The Role of Institutions and Social Learning in Soil Conservation Innovations: Implications for Policy and Practice. Environmental Science and Policy, $\operatorname{March}(27), 21-31$. https://doi.org/10.1016/j.envsci.2012.10.020

13. Elizabeth, R., \& Anugrah, S. (2014). Economic Institution on Vegetables Farmers Community in Bali Province. Pusat Analisis Sosial Ekonomi Dan Kebijakan Pertanian, 134-146. 
14. Faith, C. (2013). New Media and Sustainable Agricultural Development in Nigeria. 20, 66-74.

15. FAO. (2017). Information and Communication Technology ( ICT ) in Agriculture: A Report to the G20 Agricultural Deputies. http://www.fao.org/3/a-i7961e.pdf

16. Fischer, E., \& Qaim, M. (2012). Linking Smallholders to Markets: Determinants and Impacts of Farmer Collective Action in Kenya. World Development, 40(6), 1255-1268. https://doi.org/10.1016/j.worlddev.2011.11.018

17. Hariadi, S. S. (2011). Dinamika Kelompok (Teori dan Aplikasinya untuk Analisis Keberhasilan Kelompok Tani sebagai Wahana Belajar, erjasama, Produksi, dan Bisnis). Sekolah Pasca Sarjana Universitas Gadjah Mada.

18. Harinie, L. T., Sudiro, A., Rahayu, M., \& Fatchan, A. (2017). Study of the Bandura' s Social Cognitive Learning Theory for the Entrepreneurship Learning Process. 6(1), 1-6. https://doi.org/10.11648/j.ss.20170601.11

19. Hoffmann, V., Probst, K., \& Christinck, A. (2007). Farmers and Researchers: How Can Collaborative Advantages Be Created in Participatory Research and Technology development? Agriculture and Human Values, 24(3), 355-368. https://doi.org/10.1007/s10460-007-9072-2

20. Jamaluddin, N. (2013). Adoption of E-Commerce Practices among The Indian Farmers, a Survey of Trichy District in the State of Tamilnadu, India. Procedia Economics and Finance, 7(Icebr 2013), 140-149. https://doi.org/10.1016/S2212-5671(13)00228-1

21. Kabir. (2012). Attitude and Level of Knowledge of Farmer on ICT based Farming. European Academic Research, 2(10), 13177-13196.

22. Kahar, R., Yamimi, F., Bunari, G., \& Habil, H. (2012). Trusting the Social Media in Small Business. Procedia Social and Behavioral Sciences, 66, 564-570. https://doi.org/10.1016/j.sbspro.2012.11.301

23. KOMINFO RI. (2015). Pemanfaatan dan Pemberdayaan TIK pada Petani dan Nelayan ( Survey Rumah Tangga dan Best Practices ).

24. Kutwa, A. A., Muhingi, W. N., \& Kokonya, D. (2016). Smallholder Rural Youth Farming in Kiambu County , Kenya. Journal Pf Culture, Society and Development, 25(November), 60-71.

25. Laforge, J. M. L., \& McLachlan, S. M. (2018). Learning Communities and New Farmer Knowledge in Canada. Geoforum. https://doi.org/10.1016/j.geoforum.2018.07.022

26. Lokeswari, K. (2016). A Study of the Use of ICT Among Rural Farmers. International Journal of Communication Research, 6(3, July), 232-238.

27. Magnan, N., Spielman, D. J., Lybbert, T. J., \& Gulati, K. (2015). Leveling With Friends: Social Networks and Indian Farmers' Demand for a Technology with Heterogeneous Benefits. Journal of Development Economics. https://doi.org/10.1016/j.jdeveco.2015.05.003

28. Makalew, J., Kusuma, Z., \& Tamod, Z. (2013). The Influence of Farmer Characteristic and Farming to the Farmer Motivation on Using Organic Manure ( Case Study in East Tombatu District, South-East Minahasa Regency ). 3(August), 43-51.

29. Noorani, M. (2015). To Farm or Not to Farm? Rural Youth Perceptions of Farming and their Decision of Whether or Not to Work as a Farmer: A Case Study of Rural Youth in Kiambu County, Kenya (Issue January). School of International Development and Global Studies Faculty of Social Sciences University of Ottawa.

30. Ogunniyi, M. D., \& Ojebuyi, B. R. (2014). Mobile Phone Use for Agribusiness by Farmers in Southwest Nigeria. Journal of Agricultural Extension, 20(2011), 51-61. https://doi.org/10.4314/jae.v20i2.13

31. Park, J. Y. (2017). Does Social Media Use Influence Entrepreneurial Opportunity? A Review of its Moderating Role. 1-16. https://doi.org/10.3390/su9091593

32. Prayoga, K., Subejo, \& Raya, A. B. (2019). Young Farmers and Digitalization: From Price Taker to Price Maker. International Graduate Student and Scholars Conference in Indonesia, 2011, 181-188. https://doi.org/10.18502/kss.v3i20.4935

33. Rani, P. U., \& Padmalosani. (2019). Impact of Social Media on Youth. International Journal of Innovative Technology and Exploring Engineering, 8(11 $\quad$ September), 786-787. https://doi.org/10.35940/ijitee.K1138.09811S19

34. Rasmikayati, E., Setiawan, I., \& Saefudin, B. R. (2017). Kajian Karakteristik Perilaku dan Faktor Pendorong Petani Muda Terlibat dalam Agribisnis pada Era Pasar Global. Mimbar Agribisnis, 3(2), 134-149. https://doi.org/10.25157/ma.v3i2.565

35. Raya, A. B. (2014). Farmer Group Performance of Collective Chili Marketing on Sandy Land Area of Yogyakarta Province Indonesia. Asian Social Science, 10(10), 1-12. https://doi.org/10.5539/ass.v10n10p1

36. Raya, A. B., Kriska, M., Wastutiningsih, S. P., Umi, M., Djitmau, A., \& Cahyani, G. F. (2018). Strategy for Utilizing DesaApps Applications in Agriculture Information. 16(2), 274-285. https://doi.org/10.29244/jurnalkmp.16.2.274-285

37. Rogge, N., Theesfeld, I., \& Strassner, C. (2020). Learning, Culture and Social Interaction The Potential of Social Learning in Community Gardens and the Impact of Community Heterogeneity. Learning, Culture and Social Interaction, 24(August 2019), 100351. https://doi.org/10.1016/j.lcsi.2019.100351

38. Rusdiyana, E. (2018). Peran Pasar Lelang dalam Pemasaran Cabai di Kelompok Tani Lahan Pasir Pantai Kulonprogo, Yogyakarta. Caraka Tani: Journal of Sustainable Agriculture, 32(2), 1-8. 
https://doi.org/10.20961/carakatani.v32i1.14666

39. Santrock. (2012). Life Span Development (Perkembangan Masa Hidup). Airlangga.

40. Schneider, F., Ledermann, T., Rist, S., \& Fry, P. (2009). Social learning processes in Swiss soil protection - The "From Farmer - To Farmer" project. Human Ecology. https://doi.org/10.1007/s10745-009-9262-1

41. Schroeder, R. (2018). The Internet in Theory. In Social Theory after The Internet (pp. 1-27). UCL Press. https://doi.org/10.2307/j.ctt20krxdr.4

42. Subejo, Ineke, R., Kriska, M., Tsaqib, N., Intan, A., Dwi, A., \& Mei, P. (2018). Akses, Penggunaan Dan Faktor Penentu Pemanfaatan Teknologi Informasi Dan Komunikasi Pada Kawasan Pertanian Komersial Untuk Mendukung Ketahanan Pangan Di Perdesaan Yogyakarta. Jurnal Ketahanan Nasional, 24(1), 60-76. https://doi.org/10.22146/jkn.30270

43. Sulaksana, J. (2011). The Process of Motivations Change in Farmer Groups. Journal of Applied Science, 11(4), 2500-2512. https://doi.org/10.3923/jas.2011.2500.2512

44. Vidanapthirana, Nisansala, Sriwarnsinghe, \& Nelka. (2019). Socio Economic Develompent Sof Farmer ICTBased Education Band Rural Entrepreneurship Development. Proceedings of EDULEARN15 Conference 6th8th July 2015, Barcelona, Spain, October, 4327-4333.

45. Zhang, Y., Wang, L., \& Duan, Y. (2016). Agricultural Information Dissemination Using ICTs: A Review and Analysis of Information Dissemination Models in China. Information Processing in Agriculture, 3, 17-19. https://doi.org/10.1016/j.inpa.2015.11.002 